\title{
On Defining the Participatory Museum: The Case of the Museum of the Second World War in Gdansk
}

\author{
Ewa Manikowska - Andrzej Jakubowski
}

\author{
Ewa Manikowska \\ $\mathrm{PhD}$, Associate Professor \\ Institute of Art \\ Polish Academy of Sciences \\ Warsaw, Poland \\ e-mail: ewa.manikowska@ispan.pl \\ ORCID: 0000-0001-6633-823X \\ Andrzej Jakubowski \\ $\mathrm{PhD}$, Assistant Professor \\ Institute of Legal Studies \\ University of Opole \\ Opole, Poland \\ e-mail: andrzej.jakubowski@uni.opole.pl \\ ORCID: 0000-0002-4914-7068
}

Muzeológia a kultúrne dedičstvo, 2021, 9:4:41-55

DOI: $10.46284 / \mathrm{mkd} .2021 .9 .4 .3$

On Defining the Participatory Museum: The Case of the Museum of the Second World War in Gdansk This article seeks to contribute to the current debate on the new definition of the "museum" - a debate which led to turmoil at the 2019 ICOM General Assembly in Kyoto. With reference to the case study of the Museum of the Second World War in Gdansk (MSWW), it analyses the new and very successful genre of the narrative museum, a genre which arguably fulfils the core elements of the definition currently being discussed by ICOM. In this regard, it brings into focus the paramount importance of community involvement in creating and managing narrative museums - an aspect that has been virtually absent in the academic and media debates over the nature of the MSWW and its programme. By pointing out the fragility of the foundations for such participation, based solely on trust between communities, the museum, and state authorities, this article calls for and provides guidance for an academic and institutional redefinition of the narrative museum and the institution of a museum in general.

Keywords: narrative museum, participation, community, human rights, Museum of the Second World War in Gdansk

\section{Introduction}

On 23 March 2017, an unusual inauguration ceremony took place for the Museum of the Second World War (MSWW). While the grand openings of other important Polish museum institutions of the twenty-first century - the Warsaw Rising Museum (WRM) in 2004, or the Museum of the History of Polish Jews (Polin) in 2014 - were conceived of as true spectacles, held outdoors in order to accommodate the officials, invitees and crowds of onlookers, the MSWW's inauguration gathered together only an intimate group of its donors and some school students. In his short speech, Paweł Machcewicz, the Museum's Director, expressly referred to the participatory significance of this institution: “The first to cross [the MSWW's] threshold will be those for whom and thanks to whom it was built: prisoners of concentration camps, deportees, veterans, the museum's donors. Young people are also with us; museums shape 
historical awareness."1 The opening ceremony was truly touching, and the image of Machcewicz guiding Joanna Muszkowska-Penson, a war veteran and survivor of the concentration camp in Ravensbrück, ${ }^{2}$ became iconic. However, this image and its universal message were quickly overshadowed by political disputes regarding the public memory aspect of the Second World War in Poland. ${ }^{3}$

In this article, we do not intend to engage in the debates over the conflicting visions of history and the politics of memory of the Second World War in contemporary Poland, or in Eastern Europe more generally. Instead, we focus on the particularities of the MSWW's institutional and societal design by analysing its community and participatory grassroots. We argue that this inclusiveness is of paramount importance, as it will constitute the essence of museums as institutions in the twenty-first century. We further enquire as to why this aspect has been neglected in the vast media coverage, scholarly studies, and popular and academic discussions surrounding the MSWW since its foundation in 2008. ${ }^{4}$ In our analysis, we first point to and tackle the core shortcomings in the academic and legal definition of "narrative museums" in Poland, of which the MSWW is an excellent example. By analysing this case study, we seek to demonstrate the inherent value of community involvement for the establishment and activity of such institutions. Not only do we refer to participation as an element of museums' interaction with the audience, but we also seek to outline the relevance of participatory governance for the present-day museum sector. We examine the MSWW in the larger legal and policy framework of international cultural heritage. In this regard, we also recall the recent definition of the museum proposed on the occasion of the 2019 ICOM General Assembly in Kyoto. While acknowledging the shortcomings of this new definition, we argue that it should nevertheless serve as a starting point for considering the very essence of the narrative museum, both in the Polish legal and institutional framework and in the larger academic and public debates.

\section{Imagining the narrative museum}

Narrative museums are considered a key element of the "museum boom" in Poland, a phenomenon dating back to 2004, that is, to the year marked by Poland's accession to the European Union (EU) and by the inauguration of the WRM, the first Polish institution defined as a narrative museum. ${ }^{5}$ The WRM, due to its exceptional popularity, has become an important reference point for many other new museums in Poland. The EU structural funds, as well as grants from the EEA and Norway, have significantly contributed to the modernisation of many existing museums, the founding of new ones, and support for their educational programmes. In fact, a significant share of these funds has been allocated for establishing narrative museums and to finance their activities. To name just a few of the best-known institutions which have recently opened in Poland, we could list the European Solidarity Centre (ESC) (2014), the Emigration Museum in Gdynia (2015), the Pan Tadeusz Museum in Wrocław (2016), and the

\footnotetext{
${ }^{1}$ Otwarcie Muqeum II Wojny [The Inauguration of the MSWW], accessed February 2, 2021, https://muzeum1939.pl/ otwarcie-muzeum-ii-wojny-swiatowej/aktualnosci/146.html,

${ }^{2}$ Ex.: WWII Museum Opens in Gdańsk, accessed February 2, 2021, https://www.gettyimages.com/detail/news-photo/pawel-machcewicz-the-second-world-war-museum-director-and-news-photo/656816138.

${ }^{3}$ See: MACHCEWICZ Pawel. The War That Never Ends. The Museum of Second World War in Gdańsk. Berlin/Boston: DeGruyter 2019, pp. 154-172.

${ }^{4}$ WNUK Rafał. Wojna o wojnę. Spór o wystawę Muzeum II Wojny Światowej [A War about War. The Conflict Surrounding the Exhibition of the MSWW]. In: Res Historica 2018, pp. 335-50.

${ }^{5}$ For more on the museum boom in Poland, see among others: FONTANA Erica. Meanings of the "Museum Boom" in Poland and Elsewhere. In: Museum Anthropology, vol. 43, 2020, pp. 45-59.
} 
Sybir Memorial Museum in Białystok (2021).

Narrative museums stand out in today's Polish museum landscape, in that they reflect both the new social, cultural, economic and political environment brought about by democratisation and Poland's EU membership, and the current global trends in museology and heritage management. At the same time, however, they demonstrate a distinctive regional focus. In Poland, the narrative museum is identified in the first instance with a historical museum. By displaying and "narrating" phenomena and events of the recent Polish past (such as the Holocaust, the Warsaw Uprising and the Solidarity Movement) they have become important and appealing spaces of public history. Narrative museums are also among the main tourist highlights, and they annually record a growing number of visitors, both from Poland and abroad.

But generally speaking, the two-pronged question still remains: What is a narrative museum, and how should it operate?

Undoubtedly, this term was originally coined in relation to the United States Holocaust Memorial Museum (USHMM), today considered as the model of and inspiration for narrative museums worldwide, in particular of several Polish ones (the WRM, the Polin, and the MSWW). At the time of the inauguration of the USHMM's permanent exhibition, Jeshajahu Weinberg, its co-author and the first Director of this institution, described the USHMM as "a narrative rather than a collection based museum." "He also stressed that "the museum had to expose the universal implications hidden behind the appearance of ethnic specificity", offering a universal metaphor. ${ }^{7}$ In other words,

The dialectical tension between ... the two poles - historical and metaphorical - is the essence of the museum.... One can actually say that the museum's educational work is taking place in the space created between one pole and the other, and it is only in this way that its educational mission can be realized. ${ }^{8}$

In Poland, Weinberg's definition has been adopted only to a certain extent. In fact, one gets the impression that scholars and journalists have taken the "narrative" character of the USHMM's permanent exhibition to heart, while paying less attention to his emphasis on the evidence-based, objective and universal nature of such an educational "narration." The term "narrative museum" is a label denoting a unique institution, distinguished by its appealing and interactive methodology of display - based on multimedia and interactive scenography - which is distinct from the traditional object-centred museum. ${ }^{9}$ Accordingly, narrative museums are seen through the prism of such narrative exhibitions, whereas the educational functions appear to be reduced to a mere interaction with new forms of display and visitors' engagement.

\footnotetext{
${ }^{6}$ WEINBERG Jeshajahu. A Narrative History Museum. In: Curator. The Museum Journal, vol. 37, 1994, p. 232.

${ }^{7}$ WEINBERG, A Narrative..., pp. 238-239.

${ }^{8}$ WEINBERG, A Narrative..., pp. 238-239; EDKINS Jenny. Trauma and the Memory of Politics. Cambridge: Cambridge University Press 2002, pp. 153-164.

${ }^{9}$ See among others: WOLSKA-PABIAN Karolina, KOWAL Paweł (eds.). Muzeum $i$ zmiana. Losy muzeów narracyjnych [Museum and Change. The Fate of Narrative Museums]. Warszawa-Kraków: Universitas 2019; KOSTRO Robert, WÓYCICKI Kazimierz, WYSOCKI Michał (eds.). Historia Polski od-nowa. Nowe narracje historii i muzealne reprezentacje przeszlości [A New Polish History. New Historical Narrations and Representation of the Past in Museums]. Warszawa: Muzeum Historii Polski 2014; KOBIELSKA Maria (ed.) Muzea na widoku [Museums on View]. Special issue of Teksty Drugie 2020, no. 4.
} 
Significantly, the academic and public debate surrounding narrative museums in Poland has been shaped by scholars and professionals from outside the traditional museum field and museology. In particular, the number, popularity, and importance of narrative museums addressing recent events and phenomena have made these institutions a fascinating research field for a variety of scientific disciplines: history, political science, cultural studies, memory studies, sociology and even psychology. With the field of enquiry reduced to exhibition - the story that it tells, the means of display, and its persuasiveness and interactivity - the narrative museum is considered in the first instance as an important element shaping public memory in contemporary Poland. This is not surprising. Narrative museums are focused on landmark - but often controversial - events and phenomena from Poland's recent history. At the same time, however, the narrative museum is generally perceived as a top-down institution, and its close link with politics is not only acknowledged but is taken for granted. Therefore, it appears that most of the scholarly debate in Poland on narrative museums relates to official public history-making, and official public history practices.

An important challenge one faces when trying to define the "narrative museum" is also its lack of an underlying formal, legal notion. In fact, the narrative museum does not constitute a distinct category of museum or any other cultural institution under Polish law. In other words, the law does not separately regulate their organisation and functioning, nor does it refer specifically to "narrative" exhibitions. ${ }^{10}$ In practice, the founding statutes (charters) of all institutions defined as "narrative museums" in the literature and in the media follow a nearly uniform model and similar wording. These documents do not mention the "narrative" exhibition. Instead they address the tasks typical for a "traditional" museum. Hence, contrary to the aforementioned doctrinal views, the statutory activity of narrative museums is centred around a collection which they are obliged to form, register and research, as well as engage in the preservation of exhibits and provision of access to them. What is new vis-à-vis "narrative" museums - when compared to traditional museums - is the emphasis on their wide-ranging commemorative, educational and community-focused activities and programmes. For instance, the WRM conducts “activities related to the integration of veterans' and soldiers' communities, and activities aimed at educating the young generation of Poles in the spirit of patriotism and respect for national traditions." In turn, Polin "support[s] the activities meant to educate the young generation in the spirit of mutual tolerance and respect for the Jewish tradition and culture."12

Taking into account Poland's historical, legal and institutional context, it is also important to stress the novelty of community engagement in narrative museums. In fact, the post-war nationalisations of cultural heritage and the centralisation of memory institutions greatly undermined the strong nineteenth-century civic and participatory tradition which stood at their origins. Narrative museums, by involving direct witnesses and participants of the events in the focus of their exhibitions and activities (war veterans, Holocaust survivors, the Solidarity movement's leaders etc.), and by addressing their programmes to other - in particular to

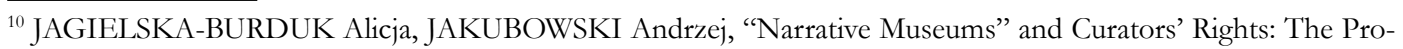
tection of a Museum Exhibition and Its Scenario under Polish Law. In: Santander Art and Culture Law Review, vol. 6, 2020, pp. 159-166.

${ }^{11}$ Statut Mureum Ponstania Warszanskiego [Statute of the WRM], Chapter 2 par. 4, accessed January 20, 2021, http:// starastrona2015.1944.pl/img/mainImages/file/XXXVI_886_2012\%20załącznik\%20_\%20aktualna.pdf.

${ }^{12}$ The Statute of POLIN, Museum of the History of Polish Jens, Chapter 2 par. 3.1, accessed January 20, 2021, https:// www.polin.pl/en/about-museum/statute.
} 
younger - generations, contribute to the re-establishment of the broken ties between museums as institutions and the wider society (individuals, communities and groups). Hence, the publichistory-making role of Polish narrative museums is more complex than the straight-forward, centralised, top-down official processes as described in the mainstream research and public debate. It also goes far beyond the interactive narrative of permanent exhibitions. Based on curatorial and community engagement, and on the balance between historic expertise and individual experience - accomplished both via the narrative exhibition and a rich array of educational activities and programmes - new narrative museums apparently fulfil what Weinberg described as a "universal metaphor", or to put it more generally, they pursue a broader educational objective and mission. In this context, it is worth quoting the following lines in the MSWW's short mission statement, which precisely illustrates such an educational and inclusive scope of the narrative museum: "We want the experiences of different nations to come together in one place. This will give us a chance to understand each other better, without crossing out the differences that have shaped us. After all, the effects of the Second World War in many dimensions continue to this day, affecting the course of borders, relations between nations, and ways of thinking." 13

\section{Defining participation}

There is no doubt that the operationalisation of narrative museums in Poland extends beyond both their legal regulation, which fails to recognise their specificity, and the doctrinal voices, which primarily address the interactive character of permanent exhibitions or refer to the role of such institutions in public memory-building. Instead, as has already been highlighted, the objectives and functions of narrative museums go far beyond the traditional approaches. This raises the question of how these new functions and fields of action can be defined and substantiated by law.

Manifestly, the key context in which the contemporary social functions of narrative museums needs to be discussed is that of participation. Indeed, since the first decade of the twenty-first century participation has become an important topic in both the Polish scholarship on museums and in museum practice. Significantly, this term has particularly been used with regard to "narrative museums", ${ }^{4}$ and its meaning is inspired primarily by Nina Simon's influential book on the participatory qualities of an interactive and engaging museum design and techniques. ${ }^{15}$ In this guise, the term "participation" refers to the methodologies for making visitor participation and community engagement more dynamic and relevant. ${ }^{16}$ In this article, however, we intend to address a distinct, broader meaning of participation. Indeed, Simon herself has recently admitted that her original vision did not truly capture the substance of participation: "If participation was my mantra from 2007-2011, community has been my mantra since then." ${ }^{\prime 7}$ In this regard, we refer to participation as community engagement in all aspects

\footnotetext{
${ }^{13}$ Raport z. dziatalności Muzeum II Wojny Światowej za 2010 rok [Raport of the Activity of the MSWW in 2010], accessed February 1, 2021, https://muzeum1939.pl/u/pdf/af0876a7fcc8938f3361500922a60cfe285.pdf.

${ }^{14}$ JAGODZIŃSKA Katarzyna. Grancie partycypacji w muzeum? [The Limits of Participation in a Museum?]. In: Muzealnictwo, vol. 57, 2016, pp. 112-121.

${ }^{15}$ SIMON Nina. The Participatory Museum. Santa Cruz, CA: Museum 2.02010.

${ }^{16}$ PADIGLIONE Vincezo. "Let the Silent History Be Told": Museum Turn to Narratives. In: Fractal: Revista de Psicologia 28, 2016, p. 181.

${ }^{17}$ SIMON Nina. The Participatory Museum, Five Years Later, accessed February 2, 2021, http:/ /museumtwo.blogspot. com/2015/03/the-participatory-museum-five-years.html.
} 
of the museum's activity. Put differently, we view participation as not being confined only to peoples' interaction with the narrative exhibition. Yet at the same time we do not use the term "community museum", as this was coined in the 1970s to denote institutions whose primary responsibility is to meet the needs of local communities. ${ }^{18}$ Such museums, particularly popular in Latin America, are "born in, created, run and managed by the community." 19 Moreover, they have often been created in opposition to official institutions, to express and reinforce the memories and identities of marginalised groups, often touching upon cultural justice agendas.

Our understanding of participation with regard to museums' social role is essentially rooted in a broader reading of human rights standards in relation to culture and heritage. In this regard, the Recommendation concerning the protection and promotion of museums and collections, their diversity and their role in society, adopted by the UNESCO General Conference in 2015 ("2015 UNESCO Recommendation"), ${ }^{20}$ is of paramount importance. This document reaffirms that "museums and collections contribute to the enhancement of human rights." Moreover, it makes a clear reference to universally recognised and protected human rights: the right to participate in the cultural life of the community, and the right to education (Preamble, $6^{\text {th }}$ Recital). Hence the social role of museums is seen as a method or means of realising cultural human rights, in both their individual and collective dimensions. Museums "can therefore play an important role in the development of social ties and cohesion, building citizenship, and reflecting on collective identities" (Paragraph 17). Accordingly, such institutions, defined as "spaces for cultural transmission, intercultural dialogue, learning, discussion and training, also play an important role in education". They also "have great potential to raise public awareness of the value of cultural and natural heritage and of the responsibility of all citizens to contribute to their care and transmission" (Paragraph 2). This participatory scope of museums should also be mirrored in their communication policies, as their "actions should also be strengthened by the actions of the public and communities in their favour" (Paragraph 11).

Such a broad understanding of participation also lies in the core of the ongoing debate on the new definition of the museum launched by ICOM in 2017. This alternative definition was selected by ICOM's executive board and initially scheduled for a vote on whether to be included in the ICOM Statutes at the 2019 Extraordinary General Assembly of ICOM in Kyoto. ${ }^{21}$ It states that: "Museums are democratising, inclusive and polyphonic spaces for critical dialogue about the pasts and the futures." Moreover, they

safeguard diverse memories for future generations and guarantee equal rights and equal access to heritage for all people. ... They are participatory and transparent, and work in active partnership with and for diverse communities to collect, preserve, research, interpret, exhibit, and enhance understandings of the world, aiming to contribute to human dignity and social justice, global equality and planetary wellbeing.

\footnotetext{
${ }^{18}$ TERUGGI Mario E. The roundtable of Santiago (Chile). In: Museum International, vol. 25, 1973, pp. $129-133$.

${ }^{19}$ BROWN Karen, MAIRESSE François. The definition of museum through its social role. In: Curator. The Museum Journal, 2018, p. 530.

${ }^{20}$ Recommendation concerning the protection and promotion of museums and collections, their diversity and their role in society, accessed March 1 $1^{\text {st }}$ 2021, http://portal.unesco.org/en/ev.php-URL_ID=49357\&URL_DO=DO_TOPIC\&URL_ SECTION=201.html.

${ }^{21}$ ICOM announces the alternative museum definition that will be subject to a vote, accessed March 1, 2021, https://icom.museum/en/news/icom-announces-the-alternative-museum-definition-that-will-be-subject-to-a-vote.
} 
Hence, notwithstanding the criticism of the definition from ideological perspectives and the postponement of the vote on it until the next ICOM General Assembly in 2022, the new definition nevertheless reflects an array of important changes in museum practices around world. ${ }^{22}$

In relation to this initiative by ICOM, it is also necessary to highlight another key dimension of participation, namely, transparent governance in active partnership with and intended for diverse stakeholders. Indeed, the nexus between participation and governance is longstanding, and essentially linked to the concept of good governance, substantiated in international policy since the late 1980s in terms of ensuring respect for human rights, openness, transparency, and the accountability of public institutions. ${ }^{23}$ It has also been recognised that good governance should encompass culture and heritage governance, and that the human right to participate in the cultural life of the community should also be extended to include the right to participate in decision-making processes and the right to consultation and information-sharing with reference to the cultural life of a given community. ${ }^{24}$ In this regard, the value of participatory governance vis-à-vis culture is particularly enhanced at the European regional level, both by the EU and the Council of Europe (CoE). Insofar as concerns treaty law, the participatory governance of cultural heritage has been best substantiated by the CoE Convention on the Value of Cultural Heritage for Society of 2005 ("Faro Convention"), ${ }^{25}$ which posited and consolidated a clear regulatory bridge between the human right to participate in cultural life and cultural heritage governance. This international law instrument exercises a significant impact on cultural policies throughout the EU and the wider Europe. It specifies the issue of public and democratic participation in the governance of cultural heritage, emphasising "the necessity for involving all members of society in a rationale of democratic governance in all matters connected with the cultural heritage." 26 In such a guise, participatory governance and/or management is one of the main objectives of the CoE's European Cultural Heritage Strategy for the 21 st Century, adopted in 2017. In this respect it is referred to as

a shortcut for openness to the needs and expectations of stakeholders, readiness of the holders of public authority to listen to them and to provide responses to their expectations or queries, delivering public policies in a spirit of openness, accountability and shared ownership. ${ }^{27}$

Participatory governance also constitutes one of the pillars of the EU's agenda for cultural heritage. Importantly, in 2014 the Council of the EU issued its Conclusions on the participatory governance of cultural heritage. ${ }^{28}$ This instrument, presenting the EU's political position and joint objectives towards heritage, recognises that participatory governance in this policy area "offers opportunities to foster democratic participation, sustainability and social cohesion and to face the social, political and demographic challenges of today" (Paragraph 8). Hence it calls

\footnotetext{
${ }^{22}$ BROWN, MAIRESSE, The definition ..., pp. 531-534.

${ }^{23}$ See, ex. ANNAN Kofi. The Quiet Revolution. In: Global Governance, vol. 4, 1998, pp. 123-138.

${ }^{24}$ ROMAINVILLE Céline. Defining the Right to Participate in Cultural Life as a Human Right. In: Netherlands Quarterly of Human Rights, vol. 33, 2015, pp. 405-436.

${ }_{25}$ Convention on the Value of Cultural Heritage for Society, accessed March 2, 2021, https://www.coe.int/en/web/culture-and-heritage/faro-convention.

${ }^{26}$ Convention on the Value of Cultural Heritage for Society - Explanatory Report, accessed March 2, 2021, http://www. worldlii.org/int/other/COETSER/2005/5.html.

${ }^{27}$ Recommendation of the Committee of Ministers to member States on the European Cultural Heritage Strategy for the 21st Century, accessed March 2, 2021, https://rm.coe.int/16806f6a03.

${ }^{28}$ Council's conclusions on participatory governance of cultural heritage, accessed March 2, 2021, https://eur-lex.europa.eu/ legal-content/EN/TXT/?uri=CELEX\%3A52014XG1223\%2801\%29.
} 
for joint efforts on the part of the European Commission and Member States to engage a variety of stakeholders in the realm of cultural heritage. These policy objectives are further developed in Decision (EU) 2017/864 of the European Parliament and of the Council, establishing a European Year of Cultural Heritage (2018). ${ }^{29}$ In its Preamble, while acknowledging that people and human values need to be put "at the centre of an enlarged and cross-disciplinary concept of cultural heritage" (Paragraph 13), it also states that "In order to realise fully the potential of cultural heritage for European societies and economies, the safeguarding, enhancement and management of cultural heritage require effective participatory (i.e. multi-level and multistakeholder) governance" (Paragraph 16).

In light of the above, a more holistic understanding of participation in relation to the social role, institutional design, and practical operationalisation of present-day museums appears fully justified, in particular with regard to those institutions which can be labelled as "narrative". Therefore, in the following section we enquire more closely into the participatory grassroots initiatives of narrative museums in Poland, while referring to the case of the MSWW. We focus on the formative years of this institution, from its foundation in 2008 until the inauguration of its permanent exhibition in 2017.

\section{The MSWW: narrative museum as a participatory museum}

The MSWW was founded as a state cultural institution in September 2008 amidst the ongoing academic and political Polish-German historical controversies centred around assessment of the post-war expulsions of Germans from the territories annexed to Poland. ${ }^{30}$ At that time, Donald Tusk, the then Polish prime minister, took up the idea launched in a press article by Machewicz (the future first Director of the MSWW) of establishing a Polish museum aimed at presenting the Polish and Central European experience of the Second World War to a wider international audience. According to Machewicz, such an institution would not only form a constructive response to the plans for establishing an educational centre and museum dedicated to the history and heritage of German expellees, but also constitute an occasion to make an important multi-faceted contribution to the shared European memory. So while the original idea for such a new institution was essentially linked to a certain "regional memory rivalry", the plans were far more ambitious, aimed at offering a universal message. In this regard however, two rather opposing questions arise: Why and to what extent is it legitimate to consider such a state-founded institution to be a truly participatory museum? And would it not be a just another official political project?

In response to these questions, we attempt here to demonstrate that even state museums with universal ambitions, such as the MSWW, can bring communities together (both on the local and transnational levels) and develop innovative, inclusive models of engagement, provided that a high degree of institutional autonomy is secured and that participatory models of governance are properly implemented.

The first dimension of the MSWW's activity that can be analysed in terms of enhanced public participation and participatory governance is that of the creation of its conceptual design. In 2008, this newly founded institution was entrusted with the task of planning and organising the future large-scale museum, and of deciding upon its location, construction,

\footnotetext{
${ }^{29}$ Decision (EU) 2017/864 of the European Parliament and of the Council of 17 May 2017 on a European Year of Cultural Heritage (2018), accessed March 2, 2021, https://eur-lex.europa.eu/legal-content/EN/TXT/?uri=CELEX$\% 3 \mathrm{~A} 32017 \mathrm{D} 0864$.

${ }^{30}$ MACHCEWICZ, The War ..., pp. 7-12.
} 
program and activities. Importantly, from the start the museum was accorded a broad autonomy. The establishment of a Board of Trustees constituted a novel solution in the Polish centralised museum system, adopted at that time in only two other memory institutions. Consisting of eleven members nominated by the Minister of Culture and National Heritage, the MSWW's Board of Trustees was given the responsibility to "oversee whether the museum fulfils its responsibilities towards the collection and the wider society." 31 Arguably, this wide autonomy and institutional framework allowed for building social capital and trust, as the newly established museum based all of its activities on public consultations and community involvement. The MSWW programme concept (2008) was first discussed with the major Polish historians of the Second World War and museum professionals, then made public on the institution's website and widely debated in important press titles. ${ }^{32}$ Despite its universal global ambitions, the museum's authors also sought to respond to the sensitivities, memories and needs of Polish society. To this end they conducted a survey (commissioned from Pentor Research International, an opinion polling institute) concerning the Polish collective memory of the Second World War. Its results, interpreted by a group of eminent sociologists specialised in collective memory, served as an important roadmap in the conceptual works of the main exhibition and of the museum's educational and scientific activity. ${ }^{33}$ The survey's results, showing that the Polish collective memory of the war concerned individual and collective experiences rather than warfare itself, confirmed the key assumption of the programme concept: the focus of the future museum and its main exhibition would be on the war-time and post-war sufferings and experiences of civilians. In addition, the actual choice of Gdansk as the museum's seat, its location within the city, the international competition for the building of the museum, and the scenography of the permanent exhibition were all subject to wide public consultations.

Importantly, the permanent exhibition was envisioned in the MSWW's programme concept as "narrative" and "interactive", with use of the most up-to-date multimedia and audio-visual tools, reconstructions and replicas. The jury of the competition for the permanent exhibition scenography consisted of distinguished artists, writers and journalists, and was presided over by the world-renowned Polish film-director, Andrzej Wajda (1926-2016). With his personal war memories and recollections, encompassing his family's tragic history (his father was executed in 1940 by the NKVD in the Katyń massacre), Wajda evaluated the project not only through the eyes of an artist, but also of a witness. ${ }^{34}$ The MSWW's Programme Board, established in 2009, was also based on a carefully designed balance between the highest expertise and the various national and personal sensibilities and experiences of those included. Thus, the appointed members, coming from Poland, Israel, Russia, Ukraine, the UK and the USA, included war and Holocaust Survivors, eminent historians of the Second World War, and directors of related memory and research institutions of world renown. ${ }^{35}$

\footnotetext{
31 Statut Muzeum II Wojny Światowej w Gdańsku [Statute of the MSWW in Gdansk,] par 11.1, accessed January 20, 2021, https://sip.lex.pl/akty-prawne/dzienniki-resortowe/utworzenie-muzeum-ii-wojny-swiatowej-w-gdansku-34267678.

${ }^{32}$ MACHCEWICZ, The War..., pp. 7-12.

${ }^{33}$ KWIATKOWSKI Piotr T., NIJAKOWSKI Lech M., SZACKA Barbara, SZPOCIŃSKI Andrzej. Między codziennościq a wielkeq historiq. Druga wojna światowa w pamięci zbiorowej polskiego społeczeństwa [Between the Everyday and Great History. The Second World War in Collective Memory of Polish Society]. Gdańsk-Warszawa: Scholar 2010.

${ }^{34}$ MACHCEWICZ, The War..., p. 51.

${ }_{35}$ Skład Kolegium Programowego Muzeum II Wojny Światowej $w$ Gdansku [Membership of the Steering Committee of the MSWW in Gdanks], accessed February 2, 2021, https://muzeum1939.pl/sklad-kolegium-programowego-muzeum-ii-wojny-swiatowej/aktualnosci/533.html.
} 
Considering the political, social and cultural differences, the MSWW consultation and management process can be compared to that of the USHMM, which was the prototype of the narrative museum. In 1978, US President Jimmy Carter established - within a broader foreign policy agenda - the Presidential Commission on the Holocaust, consisting of Holocaust Survivors, lay and religious leaders of all faiths, scholars, and Senators and Congressmen, presided over by Elie Wiesel, a Holocaust Survivor. ${ }^{36}$ The Commission was entrusted with the task of preparing a report on the following issues: the main lines for establishing a Holocaust memorial; the possibility of obtaining contributions of the American people for this project; and the recommended ways of commemorating the American Holocaust Remembrance Days. While preparing the report, the Commission engaged in wide civic consultations and public hearings involving thousands of interviewees. Meaningfully, the Commission concluded with a call for a museum-memorial in Washington DC and explained that, "In many respects, the recommendations and proposals of the Commission reflect the collective wisdom gleaned from discussion with a broad cross-section of individuals and groups." ${ }^{37}$ It should be noted here that while the USHMM is strongly rooted in the well-grounded American tradition of public-private partnerships, the MSWW was founded in a completely different legal and social framework, in which museum institutions are managed and sponsored almost exclusively by the public sector. However, just like in the case of the USHMM, its authors attempted to listen carefully to the views of the communities whose past heritage was placed at the heart of this new institution. Moreover, the participatory design of the MSWW not only concerned its inception and conceptual model, but was reflected in the operations it pursued alongside the works on the permanent (narrative) exhibition.

The second dimension of the MSWW's participatory design relates to its collection-building process. The MSWW from its inception established contacts, both in Poland and abroad, with individuals, memory institutions, specialised antique shops and auction houses, scholars, collectors, and even treasure hunters, resulting in numerous acquisitions, gifts, long-term loans and replicas of museum objects, as well as digital witness accounts for the MSWW's collections and for its main exhibition. While working on the exhibition scenario, its authors realised that the best way to explain even the most fundamental concepts and historical facts was through tangible objects and personal stories, not necessarily linked to war heroes or famous persons. In 2011 they launched a nationwide collection initiative, asking for donations of historical documents and everyday objects relating, inter alia, to the fate of civilians in armed conflicts, occupations, genocide, and forced migrations. ${ }^{38}$ The MSWW reassured the donors, who cherished the wartime memorabilia as family treasures, that in the new institution such objects and documents would be cared for and preserved for posterity. Furthermore, the donations and loans were accompanied by personal stories surrounding their origins and role in people's experience of the war. Sometimes such witnesses were recorded and included in the MSWW's collection, as a full and inseparable element thereof. In December 2016, at the dawn of the opening of the permanent exhibition, the MSWW's collection included over 40,000 artefacts

\footnotetext{
${ }^{36}$ LINENTHAL Edward T. Preserving Memory. The Struggle to Create America's Holocaust Museum. New York: Penguin Books 1997.

${ }^{37}$ President's Commission on the Holocaust. Report to the President $29^{\text {th }}$ September 1979, accessed January 20, 2021, https:// www.ushmm.org/m/pdfs/20050707-presidents-commission-holocaust.pdf.

${ }^{38}$ Zbieramy pamiatki dla Muzeum II Wojny Światowej. Prayłacz się! [We Are Collecting Memorabilia for the Museum of the Second World War. Join Us!], accessed January 20, 2021, https://histmag.org/Zbieramy-pamiatki-dla-Muzeum-II-Wojny-Swiatowej.-Przylacz-sie-5928.
} 
from acquisitions, donations and long-term loans, as well as 237 digital notations. ${ }^{39}$ The latter included witness testimonies recorded in various localities in Poland and abroad (Kazakhstan, Ukraine, Germany and South Korea, among others). More than 2,000 individuals and institutions have made a donation or a long-term loan to the MSWW.

Another participatory aspect of the MSWW's activity from its very inception is its wide and ambitious educational programme. In fact, long before the opening of the permanent exhibition, the "narrative" function of the museum was pursued through education. While initially addressed to the local communities of Gdańsk and the Pomerania region, the museum's educational initiatives also reached schools and groups in other regions of Poland and abroad. In particular, Westerplatte, a small peninsula in Gdansk where, on September 1, 1939, a battle between German and Polish forces marked the beginning of the Second World War, became an important space of such activity. Indeed, in the decision to locate the MSWW in Gdansk particular attention was attached to its linkage with this symbolic and important heritage site. The educational path and outdoor exhibition realised by the MSWW on Westerplatte became the focal point of outdoor educational programs, educational games and historical reconstructions involving amateur reconstruction groups. Several events were permanently inscribed in the Gdansk cultural calendar, such as the outdoor event organised on International Museum Day, the Pomeranian Science Festival, and workshops addressed to reconstruction groups Polandwide. In collaboration with other Gdansk and Polish memory institutions and schools, the MSWW has organised numerous innovative competitions and workshops addressed to school students.

Finally, participation can also be analysed in relation to the MSWW's networking agenda. In fact, the museum's programme concept stipulated that the MSWW and its activities should be inscribed in the already-existing network of museums and memory institutions of a similar profile and with similar aims. Particular emphasis was given to collaboration with the ESC, a cultural institution in Gdańsk devoted to the history of Solidarity and other opposition movements throughout Communist Eastern Europe. Indeed, the MSWW and the ESC were seen as a complementary pair of institutions devoted to the contemporary history of Poland and Central and Eastern Europe. However, the network of collaborations built by the MSWW was much larger, including not only important public research and memory institutions in Poland and abroad but also various NGOs, professional associations, schools and local authorities. The scientific activity of the MSWW, which has resulted in important research projects, conferences, workshops and publications, was also based on collaboration with scholars and with academic and memory institutions in Poland and abroad.

The yearly reports of the MSWW, the daily news releases posted on the institution's webpage from the time of its founding up to the museum's inauguration, the press coverage of its acquisitions, and the range of educational and scientific projects offer a glimpse into the complex, rich and multi-layered process of making a museum institution in which various individuals, communities and other institutions have been involved on a daily basis. In this process, a meeting of the Programme Board, the recording of a witness notation, the historical staging of the Battle of the Bulge, the visit from the Peace Boat (an organisation of Hiroshima and Nagasaki survivors which brought 1,000 origami cranes as a symbol of peace) and the trial presentations of the main exhibition to groups of museum professionals were all equally

${ }^{39}$ Raport z driałalności Muzeum II Wojny Światowej za rok 2016 [Report of the Activity of the MSWW in 2016], pp. 57-69, accessed January 20, 2021, https://muzeum1939.pl/u/pdf/1e80e8dda304fb34520c9fbffb95fcf7298.pdf. 
important. The number, variety and importance of the stakeholders involved in the MSWW's creation is also well evidenced in its collection, which besides gifts and loans from individuals, associations and institutions contains the recollections of the members of the museum's two boards and of its main authors. ${ }^{40}$ The community-based character of the MSWW is one of the most visible elements of the exhibition, the narrative of which is built around human microhistories shown together with the donated or loaned objects, photographs, documents and annotated witness accounts.

The aforementioned participatory features of the MSWW's design and activities make this institution a model example of a present-day narrative museum, bridging universal metaphor, community engagement, and innovative forms of communication with the visitors. Unfortunately, however, these participatory values remain virtually unnoticed in the public and academic debates. Instead, the discussion concerning the MSWW is almost entirely focused on the conflict between the museum's Directors and its International Programme Board on the one side, and Poland's Ministry of Culture and National Heritage on the other - a conflict which has led to the replacement of the members of the former group in a new institutional design. The conflict has been ongoing since 2015, and stemmed from harsh criticism on the part of the government of the content of the museum's permanent exhibition, and attacks on its broad scientific, management, and curatorship autonomy. More precisely, the universal message of the permanent exhibition - centred on the human rather than on purely national dimension and experience of the war - was perceived by ministerial experts as insufficiently reflecting the trauma suffered by Poles, and their martyrdom. ${ }^{41}$ Hence the MSWW has become a battlefield of conflicting visions concerning both the public memory as well as the role of a publicly funded narrative museum. ${ }^{42}$ Dominant voices in both the public and scholarly debate seem to accept this entirely politicised and ideologised language used in discussing the role of narrative museums, nearly ignoring the value of their participatory grassroots. In fact, Rafał Wnuk, the former MSWW deputy Director and one of its main authors, notes that the vast majority of voices have not in fact referred to the museum as such, but rather to the alleged mutually exclusive visions of Polish identity and Polish patriotism. ${ }^{43}$ Springing from the dominant views on the narrative museum as a space of official public memory-making, the controversies have thus been seen as just a subsequent stage in this process.

However, beyond the dominant public and academic debate, various communities closely involved in the museum-making process and in its activities (war veterans, Holocaust Survivors, donors, educators, scholars, artists, memory, academic and local government institutions, as well as the public) have stood up in defence of the MSWW's autonomy. Such support was expressed in numerous letters addressed to the Ministry of Culture and National Heritage, both during civic protests and in the press and broadcast media. Particularly touching were the individual appeals from the war victims and veterans and their relatives who contributed to the MSWW with gifts and loans of cherished documents, objects and testimonies. In particular such individual appeals and statements pointed to the museum as a common good and to the

\footnotetext{
${ }^{40}$ WNUK Rafał, MACHCEWICZ Paweł, GALKA-OLEJKO Oliwia, JASIŃSKI Lukasz. Museum of the Second World War. Catalogue of the Permanent Exbibition. Gdansk: Museum of the Second World War 2016.

${ }^{41}$ JAGIELSKA-BURDUK, JAKUBOWSKI, "Narrative Museums” ..., pp. 156-157.

${ }^{42}$ DONADIO Rachel. A Museum Becomes a Battlefield Over Poland's History. In: The New York Times", November 10, 2016, section C, p. 1.

${ }^{43}$ WNUK, Wojna o wojne ...
} 
autonomy of the people's rights to preserve and share their memories with future generations. ${ }^{44}$

\section{Concluding remarks}

Indeed, the human rights aspect of the social role of the narrative museum is undoubtedly of paramount significance. In the case of the MSWW, the support for the institution's autonomy and its communal and citizen value and meaning came in fact from the human rights field. At the national level, action to protect the museum's autonomy and to defend freedom of research and expression has been undertaken by Poland's Commissioner for Human Rights. These issues have also been recently addressed at the international level. Karima Bennoune, Special Rapporteur of the United Nations in the field of cultural rights, in her 2020 report on her visit to Poland, ${ }^{45}$ recommended that the government " $[\mathrm{r}]$ espect the artistic and scientific freedom of the directors and staff of cultural institutions and museum curators as well as the autonomy of universities and refrain from politicizing or exercising undue pressure on the content of their work", and "[s] upport the work of those seeking to display a complex vision of history and of past human rights abuses and atrocities, foster open debates about historical events and respect the integration of this complexity in school history curricula and in museums, as an important means of developing critical thinking and understanding and of shaping a tolerant and inclusive society" (Paragraph 94(b)(c)). There could hardly be a better conceptualisation of the meaning and social role of narrative museums.

Considering the above-discussed characteristics of narrative museums in Poland, it is clear that irrespective of their proliferation and success they are still very fragile entities. The foundations of their social functions - participation and participatory governance - are based solely on trust between a narrative museum and communities and state and local authorities. However, while recognising the importance of such institutions for the realisation of fundamental human rights, it also seems necessary to provide an appropriate legal and institutional framework for such participation. Moreover, it is crucial that scholars investigating contemporary museology and the phenomenon of narrative museums move away from the technological and political problems of current museum practice towards a deeper consideration of the meaning of participation, and its role in the cultural life of societies around the world.

\section{Acknowledgment}

This article was written within the framework of the research project "Digital Heritage in Cultural Con $\neg$ flicts", supported by Poland's Ministry of Culture, National Heritage and Sport under the JPICH Digital Heritage programme - support for scientific research on cultural heritage under the Joint Programming Initiative on Cultural Heritage (JPICH), No. 98/DSAPJG/2018.

\footnotetext{
${ }^{44}$ Ex.: MUSZKOWSKA-PENSON, Joanna, Odebrat mi Pan miejsce pamieci [You Took Away my Memorial Site], accessed January 20, 2021, https://wyborcza.pl/7,75968,21625775,odebral-mi-pan-miejsce-pamieci.html.

${ }^{45}$ Visit to Poland: Report of the Special Rapporteur in the Field of Cultural Rights, accessed March 3, 2021, https://undocs. org/en/A/HRC/43/50/50/Add.1.
} 


\section{References}

Policy and legal instruments:

Convention on the Value of Cultural Heritage for Society, accessed March 2, 2021, https:/ /www.coe. int/en/web/culture-and-heritage/faro-convention.

Convention on the Value of Cultural Heritage for Society - Explanatory Report, accessed March 2, 2021, http://www.worldlii.org/int/other/COETSER/2005/5.html.

Council's conclusions on participatory governance of cultural heritage, accessed March 2, 2021, https:// eur-lex.europa.eu/legal-content/EN/TXT/?uri=CELEX\%3A52014XG1223\%2801\%29.

Decision (EU) 2017/864 of the European Parliament and of the Council of 17 May 2017 on a European Year of Cultural Heritage (2018), accessed March 2, 2021, https://eur-lex.europa.eu/legalcontent/EN/TXT/?uri=CELEX\%3A32017D0864.

ICOM announces the alternative museum definition that will be subject to a vote, accessed March $1^{\text {st }} 2021$, https://icom.museum/en/news/icom-announces-the-alternative-museum-definition-thatwill-be-subject-to-a-vote.

President's Commission on the Holocaust. Report to the President 29 September 1979, accessed January 20, 2021, https://www.ushmm.org/m/pdfs/20050707-presidents-commission-holocaust.pdf.

Recommendation concerning the protection and promotion of museums and collections, their diversity and their role in society, accessed March 1, 2021, http://portal.unesco.org/en/ev.php-URL_

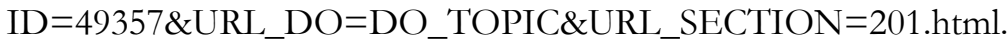

Statut Muzeum II Wojny Światowej w Gdansku [Statute of the MSWW in Gdansk], accessed January 20, 2021, https://sip.lex.pl/akty-prawne/dzienniki-resortowe/utworzeniemuzeum-ii-wojny-swiatowej-w-gdansku-34267678.

The Statute of POLIN, Museum of the History of Polish Jens, accessed January 20, 2021, https:// www.polin.pl/en/about-museum/statute.

Statut Muzeum Powstania Warszanskiego [Statute of the WRM], accessed January 20, 2021, http:// starastrona2015.1944.pl/img/mainImages/file/XXXVI_886_2012\%20załącznik\%20-\%20 aktualna.pdf.

Visit to Poland: Report of the Special Rapporteur in the Field of Cultural Rights, accessed March 3, 2021, https://undocs.org/en/A/HRC/43/50/50/Add.1.

Bibliography:

ANNAN, Kofi. (1998). The Quiet Revolution. In: Global Governance, vol. 4, pp. 123-138.

BROWN, Karen, MAIRESSE, François (2018). The definition of museum through its social role. In: Curator. The Museum Journal, vol. 61, pp. 525-539.

EDKINS Jenny. Trauma and the Memory of Politics. Cambridge: Cambridge University Press 2002. ISBN 978-05-1184-047-0.

FONTANA, Erica (2020). Meanings of the "Museum Boom" in Poland and Elsewhere. In: Museum Anthropology 43, pp. 45-59.

JAGIELSKA-BURDUK, Alicja, JAKUBOWSKI, Andrzej (2020). "Narrative Museums" and Curators' Rights: The Protection of a Museum Exhibition and Its Scenario under Polish Law. In: Santander Art and Culture Law Review, vol. 6, pp. 159-160.

JAGODZIŃSKA, Katarzyna (2016). Grancie partycypacji w muzeum? [The Limits of Participation in a Museum?]. In: Muzealnictwo 57, pp. 112-121.

KOBIELSKA, Maria (ed.) (2020). Muzea na widoku [Museums on View]. Special issue of Teksty Drugie, no. 4. 
KOSTRO, Robert, WÓYCICKI, Kazimierz, WYSOCKI, Michał (ed.) (2014). Historia Polski od-nowa. Nowe narracje historii i muzealne reprezentacje przeszłości [A New Polish History. New Historical Narrations and Representation of the Past in Museums]. Warszawa: Muzeum Historii Polski. ISBN: 978-83-60642-93-1.

KWIATKOWSKI, Piotr T., NIJAKOWSKI ,Lech M., SZACKA, Barbara, SZPOCIŃSKI, Andrzej (2010). Miedsy codziennościq a wielka historiq. Druga wojna światowa w pamieci zbiorowej polskiego społeczeństwa [Between the Everyday and Great History. The Second World War in Collective Memory of Polish Society], Gdańsk-Warszawa: Scholar. ISBN: 978-83-7383-4552.

LINENTHAL, Edward T. (1997). Preserving Memory. The Struggle to Create America's Holocaust Museum. New York: Penguin Books.

MACHCEWICZ, Pawel (2019). The War That Never Ends. The Museum of Second World War in Gdańsk. Berlin/Boston: DeGruyter ISBN: 978-31-1065-460-8.

PADIGLIONE, Vincezo (2016). "Let the Silent History Be Told”: Museums Turn to Narratives. In: Fractal: Revista de Psicologia, vol. 28, pp. 181-186.

ROMAINVILLE, Céline (2015). Defining the Right to Participate in Cultural Life as a Human Right. In: Netherlands Quarterly of Human Rights, vol. 33, pp. 405-436.

SIMON, Nina (2010). The Participatory Museum. Santa Cruz, CA: Museum 2.0. ISBN: 978-061534-650-2

TERUGGI, Mario E. (1973). The roundtable of Santiago (Chile). In: Museum International, vol. 25, pp. 129-133.

WEINBERG, Jeshajahu (1995). A Narrative History Museum. In: Curator. The Museum Journal 37, pp. 231-239.

WOLSKA-PABIAN, Karolina, KOWAL, Paweł (ed.) (2019). Muzeum i żmiana. Losy muzeów narracyjnych [Museum and Change. The Fate of Narrative Museums]. Warszawa-Krakow: Universitas. ISBN: 97883-242-3498-1.

WNUK, Rafał (2018). Wojna o wojnę. Spór o wystawę Muzeum II Wojny Światowej [A War about War. The Conflict Surrounding the Exhibition of the MSWW]. In: Res Historica, pp. 335-350.

WNUK, Rafał, MACHCEWICZ, Paweł, GAŁKA-OLEJKO, Oliwia, JASIŃSKI, Łukasz (2016). Museum of the Second World War. Catalogue of the Permanent Exhibition. Gdansk: Museum of the Second World War. ISBN: 978-83-6302-965-4. 